\title{
Stabilisasi/Solidifikasi Timbunan Tailing Penambangan Emas Rakyat Kulon Progo Menggunakan Semen Portland
}

\author{
Ihsan Aulia Pamayo dan Yulinah Trihadiningrum \\ Jurusan Teknik Lingkungan, Fakultas Teknik Sipil dan Perencanaan, Institut Teknologi Sepuluh Nopember (ITS) \\ Jl. Arief Rahman Hakim, Surabaya 60111 Indonesia \\ e-mail: trihadiningrum@gmail.com
}

\begin{abstract}
Abstrak-Penambangan emas rakyat di Kulon Progo menghasilkan limbah berupa tailing yang mengandung merkuri (Hg) dari proses amalgamasi emas. Merkuri tersebut dibuang dan ditimbun dalam tanah. Pada penambangan tersebut terdapat timbunan tailing aktif (TTA) dan tidak aktif (TTTA). Konsentrasi total merkuri pada tailing yaitu sekitar 291-314 $\mathrm{mg} / \mathrm{kg}$. Nilai konsentrasi tersebut melebihi baku mutu konsentrasi merkuri pada tailing dengan batas maksimum sebesar $75 \mathrm{mg} / \mathrm{kg}$. Stablilisasi/Solidifikasi (S/S) dapat diaplikasikan untuk remediasi lingkungan tercemar logam berat. Semen portland memiliki kemampuan sebagai binder pencemar logam berat. Tujuan pertama dari penelitian ini yaitu mengidentifikasi karakteristik dari timbunan tailing aktif dan tidak aktif. Tujuan kedua yaitu untuk menentukan komposisi optimum timbunan tailing aktif dan tidak aktif dalam proses $\mathrm{S} / \mathrm{S}$ menggunakan semen portland. Penelitian ini menggunakan dua variasi yaitu variasi jenis timbunan tailing dan variasi komposisi timbunan tailing. Variasi jenis timbunan tailing terdiri dari timbunan tailing aktif dan timbunan tailing tidak aktif. Sampel dari kedua jenis timbunan tailing divariasikan dengan semen portland pada $\%$ rasio $b / b$ 0:100, 10:90, 20:80, 30:70, 40:60, 50:50, 60:40, 70:30, 80:20, 90:10, dan 100:0. Hasil penelitian menunjukkan sampel timbunan tailing mengandung unsur clay dengan permeabilitas $\mathrm{r}$ 7,32 $\times 10^{-13}$ hingga $1,03 \times 10^{-12} \mathrm{~cm} /$ detik. Kadar air sampel TTA dan TTTA sebesar $31,77 \%$ dan $28 \%$. Konsentrasi merkuri pada sampel TTA yaitu $160-318 \mathrm{mg} / \mathrm{kg}$. Sedangkan pada sampel TTTA yaitu $94-99 \mathrm{mg} / \mathrm{kg}$. Seluruh sampel memenuhi baku mutu kuat tekan dan baku mutu TCLP yang ditetapkan. Komposisi $100 \%$ sampel TTA dan TTTA masih mampu mengikat merkuri dengan nilai kuat tekan sebesar 53 ton $/ \mathbf{m}^{2}$ dan 117 ton $/ \mathrm{m}^{2}$. Nilai TCLP untuk merkuri pada sampel TTA dan TTTA lebih rendah dari $0,0005 \mathrm{mg} / \mathrm{L}$. Hasil penelitian ini menunjukkan bahwa tanpa penambahan semen portland sebagai binder, timbunan tailing yang mengandung clay memiliki kemampuan untuk mensolidifikasi dan menstabilkan merkuri yang terkandung dalam limbah tailing, hingga memenuhi baku mutu.
\end{abstract}

Kata Kunci-merkuri, semen portland, S/S, tailing, tambang emas

\section{PENDAHULUAN}

$\mathrm{T}$ AILING merupakan limbah yang dihasilkan dari proses pengolahan mineral tambang [1]. Proses pengolahan mineral dilakukan dengan teknik amalgamasi yang mencampur bijih mineral dengan merkuri membentuk amalgam dengan media air [2]. Pertambangan emas rakyat Kulon Progo, Yogyakarta merupakan pertambangan yang menggunakan teknik amalgamasi sederhana yang menggunakan merkuri pada proses amalgamasinya. Menurut
Larasati dkk. [3], tailing dari proses amalgamasi pertambangan Kulon Progo meluap dari bak penampungan yang ada dan mengalir ke halaman rumah masyarakat sekitar. Tailing yang meluap membentuk suatu timbunan dan dibuang tanpa proses pengolahan di beberapa titik sekitar lokasi tambang. Menurut Setiabudi [2], pertambangan emas rakyat Kulon Progo terdiri dari lokasi penambangan yang aktif (TTA) dan tidak aktif (TTTA). Penambangan yang aktif memiliki tempat pembuangan dan penimbunan tailing yang masih berjalan (aktif). Penambangan yang tidak aktif merupakan tempat pembuangan dan penimbunan tailing yang sudah tidak digunakan kembali (tidak aktif). Menurut Ogola dkk. [4], terdapat beberapa logam berat yang terdapat pada tailing dari proses amalgamasi, logam - logam tersebut antara lain merkuri, timbal, arsen, dan kadmium. Merkuri merupakan logam berat yang paling dominan yang terdapat pada tailing.

Berdasarkan Peraturan Pemerintah No. 101 Tahun 2014 tentang Pengelolaan Limbah Bahan Berbahaya dan Beracun [5], tailing dari proses pengolahan bijih mineral masuk dalam daftar LB3 dari sumber spesifik khusus dengan kode limbah B416 pada kategori 2. Tailing yang disimpan harus mengikuti syarat penyimpanan sesuai Keputusan Kepala Badan Pengendalian Dampak Lingkungan No. 1 Tahun 1995 tentang Tata Cara dan Persyaratan Teknis Penyimpanan dan Pengumpulan Limbah Bahan Berbahaya dan Beracun. Berdasarkan penelitian Kalimantoro [6], total konsentrasi merkuri pada tailing penambangan emas rakyat Kulon Progo yaitu sekitar 291-314 mg/kg. Berdasarkan PP No. 101 Tahun 2014 [5], total konsentrasi maksimum merkuri pada tailing yang diizinkan yaitu $75 \mathrm{mg} / \mathrm{kg}$. Total konsentrasi merkuri pada tailing yang didapat pada penelitian Kalimantoro [6] tersebut melebihi baku mutu yang ditetapkan oleh PP No. 101 Tahun 2014. Berdasarkan kondisi eksisting pembuangan tailing yang membentuk suatu timbunan, maka perlu adanya teknik pengolahan timbunan tailing agar dapat mengurangi tingkat pencemaran sesuai dengan baku mutu yang telah ditetapkan.

Salah satu upaya yang dapat dilakukan untuk mengurangi pencemaran dari buangan produk terkontaminasi merkuri adalah dengan teknologi Stabilisasi/Solidifikasi (S/S). Menurut Andrés dkk. [7], teknologi S/S bekerja dengan membatasi kontaminasi senyawa B3 dan mendetoksifikasi kandungan racun pada limbah. Pengolahan limbah B3 dengan $\mathrm{S} / \mathrm{S}$ memiliki kelebihan yaitu penggunaan teknologi yang hemat biaya, ramah lingkungan, dan mudah untuk 
diaplikasikan [8]. Limbah B3 pada S/S dikonversi menjadi senyawa padat sehingga mengurangi tingkat pelindian kontaminan. S/S memerlukan tambahan bahan pengikat untuk mengkapsulasi kontaminan secara fisik maupun kimiawi agar terbentuk formasi yang lebih stabil [7]. Bahan pengikat yang paling umum digunakan dalam S/S limbah B3 adalah semen portland. Semen portland memiliki kelebihan yaitu umum digunakan, mudah didapat, dan bisa digunakan pada berbagai jenis limbah [9]. S/S dengan semen portland sangat efektif digunakan untuk mengikat senyawa anorganik pada limbah B3 [10].

Penelitian ini akan meneliti kemampuan metode S/S dalam mengolah timbunan tailing aktif dan tidak aktif mengandung merkuri dengan menggunakan semen portland. Karakteristik dari timbunan tailing perlu diketahui sebagai pertimbangan dalam melakukan S/S. Pada pembuatan produk S/S, variasi komposisi semen portland dan timbunan tailing akan mempengaruhi kualitas produk tersebut. Komposisi optimum campuran semen portland dan timbunan tailing perlu diketahui untuk mendapatkan produk S/S yang diinginkan.

\section{METODE PENELITIAN}

\section{A. Variabel Penelitian}

Penelitian ini dilakukan dengan 2 (dua) variabel. Variabel pertama merupakan variasi jenis timbunan tailing, yaitu timbunan tailing aktif dan timbunan tailing tidak aktif. Variabel kedua merupakan variasi komposisi timbunan tailing aktif dan tidak aktif terhadap semen portland dalam proses $\mathrm{S} / \mathrm{S}$. Variasi dari variabel kedua pada penelitian ini dapat dilihat pada Tabel 1.

Tabel 1. Variasi Komposisi Semen Portland Terhadap Variasi Jenis Timbunan Tailing

\begin{tabular}{ccc}
\hline \hline $\begin{array}{c}\text { Perbandingan Semen : } \\
\text { TTA*/ TTTA* }\end{array}$ & $\begin{array}{c}\text { Semen Portland } \\
(\mathrm{g})\end{array}$ & $\begin{array}{c}\text { TTA* }^{*} \text { TTTA* } \\
(\mathrm{g})\end{array}$ \\
\hline $100: 0$ & 300 & 0 \\
$90: 10$ & 270 & 30 \\
$80: 20$ & 240 & 60 \\
$70: 30$ & 210 & 90 \\
$60: 40$ & 180 & 120 \\
$50: 50$ & 150 & 150 \\
$40: 60$ & 120 & 180 \\
$30: 70$ & 90 & 210 \\
$20: 80$ & 60 & 240 \\
$10: 90$ & 30 & 270 \\
$0: 100$ & 0 & 300 \\
\hline \hline
\end{tabular}

*TTA - Timbunan Tailing Aktif

*TTTA - Timbunan Tailing Tidak Aktif

Penelitian ini menggunakan replikasi sebanyak dua kali pada masing - masing variasi. Massa tiap variasi sampel mengikuti ukuran dari cetakan benda uji yang disebut specimen mold yang berjenis kubus berukuran sisi $5 \mathrm{~cm}$.

\section{B. Pengambilan Sampel Timbunan Tailing}

Pengambilan sampel timbunan tailing diambil di lokasi penambangan emas Dusun Sangon II, Desa Kalirejo, Kabupaten Kulon Progo, Yogyakarta dengan total 10 titik sampling. Timbunan tailing aktif dan tidak aktif masing - masing memiliki 5 (lima) titik lokasi sampling. Pengambilan sampel dilakukan dengan metode core samplers yang mengacu pada US EPA [11]. Metode core samplers yang digunakan yaitu subsampling and compositing (multiple core samples) dengan kedalaman yang digunakan yaitu $30 \mathrm{~cm}, 60$ $\mathrm{cm}$, dan $90 \mathrm{~cm}$ pada setiap titik.

\section{Preparasi dan Pengujian Awal Sampel}

Preparasi sampel yaitu dengan melakukan penghalusan menggunakan bond balls mill dan pengeringan dengan suhu $50^{\circ} \mathrm{C}$. Kemudian sampel dihitung berat kering dan kadar air. Hal ini dilakukan karena salah satu faktor yang mempengaruhi kualitas produk S/S yaitu jumlah penambahan air dan ukuran partikel [12]. Proses stabilisasi pada sampel yang kering akan lebih mudah dan murah dibandingkan dengan sampel yang basah. Pada proses $\mathrm{S} / \mathrm{S}$, sampel yang digunakan juga tidak boleh memiliki ukuran yang besar, karena dapat mengganggu proses operasi dari mixer. Sampel diuji karakteristik awal meliputi kadar logam berat awal, $\mathrm{pH}$, suhu, dan kadar air. Semen Portland (OPC) diambil di PT Varia Usaha Gresik untuk disiapkan dalam pembuatan benda uji sesuai dengan variasi yang telah ditentukan. Semen portland yang digunakan yaitu semen portland tipe I.

\section{Pembuatan Benda Uji}

Pembuatan benda uji diawali dengan uji konsistensi normal untuk menentukan jumlah air yang dibutuhkan dalam membuat benda uji. Konsistensi normal adalah kadar air pasta semen yang apabila jarum vicat diletakkan di permukaannya selama 30 detik akan terjadi penetrasi sedalam $10 \mathrm{~mm}$ [13]. Pengujian konsistensi normal berdasarkan ASTM C187-11e1 dimana sampel diayak pada saringan $300 \mu \mathrm{m}$ sebelum pengujian konsistensi normal. Pembuatan benda uji dibuat seberat 300 gram dari total campuran dengan penambahan akuades sesuai hasil uji konsistensi normal. Benda uji dibuat menyesuaikan ukuran specimen mold yang memiliki sisi $5 \mathrm{~cm}$. Setelah benda uji dibuat maka dilakukan perawatan mortar curing selama 28 hari. Curing bertujuan untuk memperoleh kekuatan tertentu dengan mencegah penguapan air yang cepat selama terjadinya hidrasi antara semen dan air [14]. Metode curing yang digunakan yaitu burlap curing yang menggunakan kain burlap yang dibasahi secara berkala dan diletakkan di atas benda uji [14].

\section{E. Pengujian Kuat Tekan dan TCLP}

Setelah proses curing berlangsung, maka dilakukan uji kuat tekan dan uji TCLP. Uji kuat tekan adalah besarnya beban persatuan luas yang menyebabkan benda uji hancur bila diberi gaya tertentu oleh mesin tekan [16]. Seluruh benda uji dilakukan uji kuat tekan dimana harus memenuhi syarat baku mutu yang diizinkan oleh KepKa Bapedal No. 3 Tahun 1995 [17] yaitu sebesar $10 \mathrm{ton} / \mathrm{m}^{2}$. Prosedur uji kuat tekan mengacu pada ASTM C109 tentang Compressive Strength Hydraulic Cement Mortars (ukuran $50 \mathrm{~mm}$ ). Kemudian dilakukan uji TCLP (Toxicity Characteristic Leaching Procedure) untuk mengetahui potensi pelindian merkuri yang terdapat pada timbunan tailing aktif maupun tidak aktif. Baku mutu uji 
TCLP mengacu pada PP No. 101 Tahun 2014 [5] dimana kadar merkuri maksimum pada tailing yaitu sebesar 0,05 $\mathrm{mg} / \mathrm{L}$. Uji TCLP mengacu pada metode US EPA Method 1311 [18].

\section{HASIL DAN PEMBAHASAN}

\section{A. Karakteristik Bahan Penelitian}

Bahan penelitian yang digunakan yaitu semen portland tipe I, timbunan tailing aktif, dan timbunan tailing tidak aktif. Timbunan tailing aktif dan tidak aktif memiliki karakteristik berbentuk seperti lumpur berwarna cokelat keabu-abuan. Timbunan tailing aktif dan tidak aktif memiliki unsur tanah akibat kondisi eksisting dimana bak penampungan yang ada terbuat dari galian tanah yang bercampur dengan tailing. Tanah tersebut berjenis clay dimana memiliki nilai permeabilitas $7,32 \times 10^{-13}$ hingga $1,03 \times 10^{-12} \mathrm{~cm} /$ detik [19].

Hasil pengujian kadar logam berat meliputi nikel (Ni), timbal $(\mathrm{Pb})$, kadmium $(\mathrm{Cd})$, kromium $(\mathrm{Cr})$, dan arsen $(\mathrm{As})$ pada timbunan tailing aktif dan tidak aktif seluruhnya memenuhi baku mutu menurut PP No. 101 Tahun 2014, dimana nilai $\mathrm{Pb}$ sebesar $2.300 \mathrm{mg} / \mathrm{kg}$, Cd 8,6 mg/kg, Cr 3,57 $\mathrm{mg} / \mathrm{kg}$, dan arsen 2,0 mg/kg. Sementara kadar merkuri (Hg), $\mathrm{pH}$, dan kadar air pada timbunan tailing aktif dan tidak aktif dapat dilihat pada Tabel 2.

Tabel 2

Karakteristik Timbunan Tailing

\begin{tabular}{lcrrr}
\hline \hline $\begin{array}{c}\text { Timbunan } \\
\text { Tailing }\end{array}$ & $\begin{array}{c}\text { Kadar Air } \\
(\%)\end{array}$ & $\mathrm{pH}$ & $\begin{array}{c}\text { Kadar Hg } \\
(\mathrm{mg} / \mathrm{kg})\end{array}$ & $\begin{array}{r}\text { Baku Mutu } \\
\mathrm{Hg}(\mathrm{mg} / \mathrm{kg})\end{array}$ \\
\hline Aktif & 31,77 & 6,58 & $160-318$ & 75 \\
Tidak Aktif & 28,00 & 7,30 & $94-99$ & 75 \\
\hline \hline
\end{tabular}

B. Uji Kuat Tekan

1) Uji Kuat Tekan Campuran Semen Portland dengan Timbunan Tailing Aktif

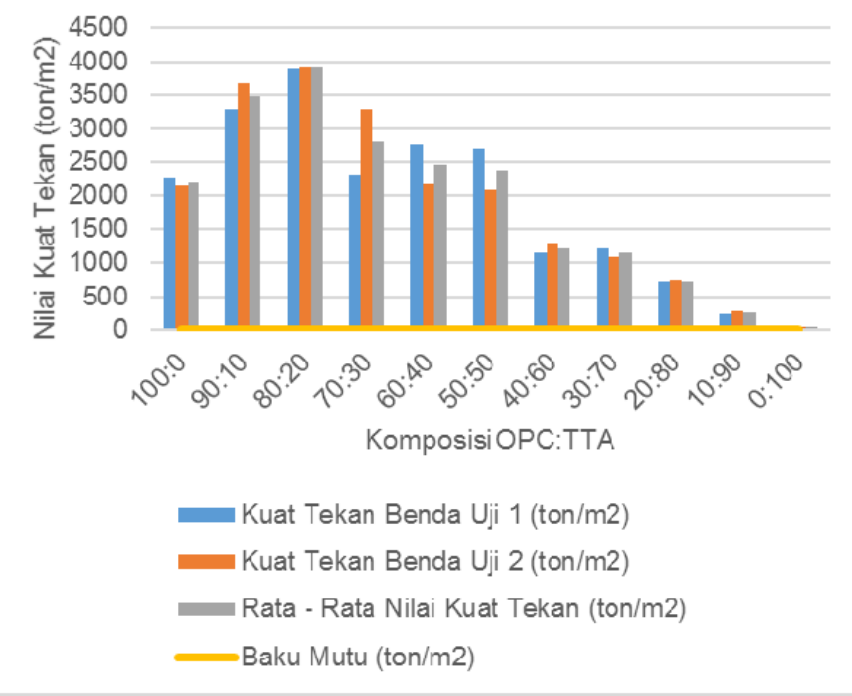

Gambar 1. Nilai Kuat Tekan Variasi Komposisi Semen Portland dengan Timbunan Tailing Aktif

Pengujian kuat tekan dilakukan pada setiap variasi komposisi antara semen portland dan timbunan tailing aktif yang dibuat duplo pada tiap benda uji. Nilai kuat tekan dapat dilihat pada Gambar 1.

Pada Gambar 1, dapat dilihat bahwa seluruh benda uji memenuhi syarat minimum kuat tekan yang ditetapkan dengan nilai kuat tekan sebesar $53 \mathrm{ton} / \mathrm{m}^{2}$ hingga $3.895 \mathrm{ton} / \mathrm{m}^{2}$. Nilai kuat tekan tertinggi yaitu pada komposisi 80:20, dan terrendah pada komposisi 0:100.

Eksistensi semen portland akan menambah nilai kuat tekan pada benda uji. Menurut Pollard dkk. [20], reaksi hidrasi semen akan menghasilkan kalsium silikat hidrat (CSH) yang memegang peranan penting dalam pengikatan kekuatan benda uji. Secara keseluruhan, nilai kuat tekan mengalami penurunan seiring dengan bertambahnya jumlah timbunan tailing. Berdasarkan penelitian Ganjidoust dkk. [9], semakin besar luas permukaan tanah akan mengurangi kinerja semen dalam mencapai kuat tekan yang diisyaratkan. Jumlah tanah yang banyak akan menutupi permukaan suatu agregat dan mencegah proses adhesi dari pasta semen.

2) Uji Kuat Tekan Campuran Semen Portland dengan Timbunan Tailing Tidak Aktif

Nilai kuat tekan variasi semen portland dengan timbunan tailing tidak aktif dapat dilihat pada Gambar 2.

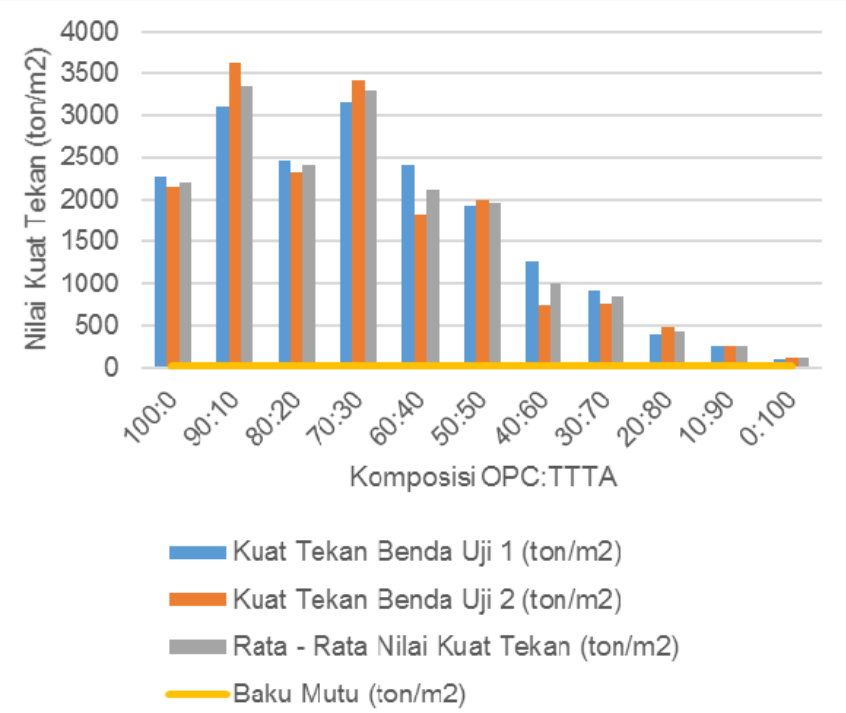

Gambar 2. Nilai Kuat Tekan Variasi Komposisi Semen Portland dengan Timbunan Tailing Tidak Aktif

Nilai kuat tekan benda uji variasi semen portland dengan timbunan tailing tidak aktif berkisar antara $106 \mathrm{ton} / \mathrm{m}^{2}$ hingga $3.362 \mathrm{ton} / \mathrm{m}^{2}$. Nilai tersebut memenuhi baku mutu minimum kuat tekan yang diperlukan. Secara keseluruhan, nilai kuat tekan benda uji dengan timbunan tailing tidak aktif memiliki grafik yang sama dengan timbunan tailing aktif, yaitu semakin bertambah timbunan maka nilai kuat tekan menurun. Namun, terjadi fluktuasi nilai kuat tekan pada komposisi 80:20, yaitu dengan nilai $2.401 \mathrm{ton} / \mathrm{m}^{2}$. Penurunan nilai kuat tekan yang terjadi pada komposisi 80:20 bisa disebabkan oleh tidak stabilnya air yang diperlukan untuk proses pengerasan pada saat curing, sehingga proses hidrasi semen terganggu [14]. Terganggunya proses hidrasi semen akan mengakibatkan berkurangnya kekuatan beton. 
3) Perbandingan Hasil Kuat Tekan Antara Variasi Timbunan Tailing Aktif dan Tidak Aktif

Pada penelitian ini, didapatkan nilai kuat tekan yang berbeda tiap jenis sampel timbunan tailing aktif dan tidak aktif. Perbedaan nilai kuat tekan dapat dilihat pada Gambar 3. Nilai kuat tekan seluruh sampel memenuhi baku mutu kuat tekan menurut KepKa Bapedal No. 3 Tahun 1995 dengan nilai yang jauh lebih tinggi. Hasil ini didapat selain karena pengaruh semen, juga bisa dikarenakan eksistensi clay pada timbunan tailing. Meskipun semakin banyak jumlah timbunan tailing akan mengurangi nilai kuat tekan, komposisi tanah berjenis clay yang cukup justru dapat meningkatkan nilai kuat tekan. Menurut He dkk. [21], mengacu pada ASTM C 618 bahwa kandungan dari $\mathrm{SiO}_{2}+\mathrm{Al}_{2} \mathrm{O}_{3}+\mathrm{Fe}_{2} \mathrm{O}_{3}$ pada pozzolan alam harus mencapai $70 \mathrm{wt} \%$, dimana clay pada umumnya memenuhi komposisi kimiawi ini. Struktur kristal, kimiawi, dan sifat partikel dari tiap jenis clay berbeda dan mempengaruhi aktivitas pozzolan dalam mencapai kekuatan mortar yang dihasilkan. Permeabilitas clay pada timbunan juga mempengaruhi nilai kuat tekan karena semakin rendah permeabilitas maka kepadatan benda uji akan semakin bagus dan potensi rongga yang terdapat pada benda uji akan semakin berkurang.

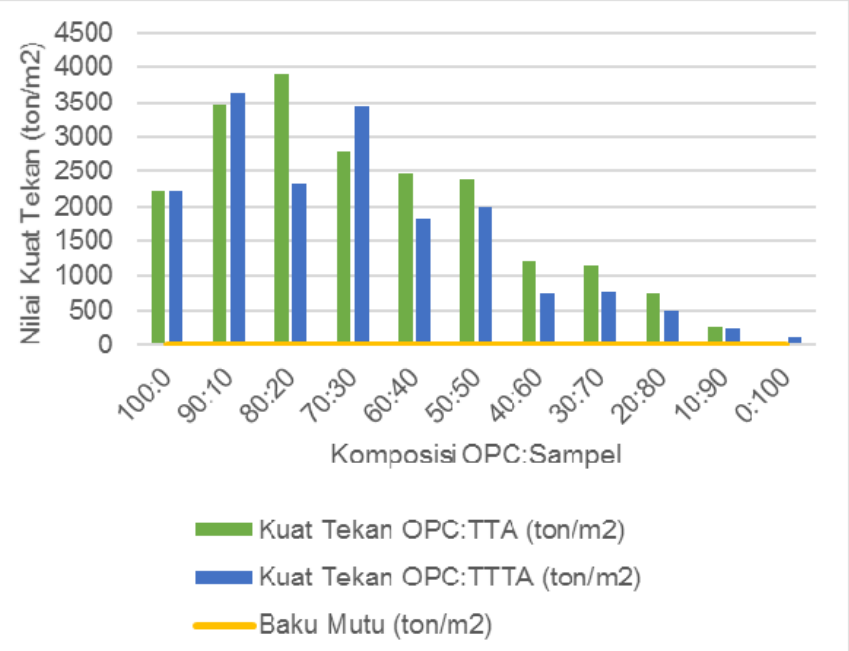

Gambar 3. Perbandingan Nilai Kuat Tekan Antara Variasi Komposisi Timbunan Tailing Aktif dengan Timbunan Tailing Tidak Aktif

Pada komposisi 100:0 pada kedua jenis sampel, nilai kuat tekan mengalami penurunan meskipun $100 \%$ komposisi semen. Hal ini bisa disebabkan oleh banyaknya kandungan $\mathrm{Ca}(\mathrm{OH})_{2}$ yang terdapat pada benda uji. Menurut Sari [22], selama proses hidrasi pada semen, akan timbul partikel $\mathrm{Ca}(\mathrm{OH})_{2}$ yang menyebabkan kekuatan semen menjadi berkurang dan menyebabkan pemekaran pada permukaan beton. Penambahan pozzolan yang mengandung silika dan alumina ke dalam semen akan bereaksi dengan $\mathrm{Ca}(\mathrm{OH})_{2}$ membentuk kalsium silikat hidrat dan kalsium aluminat hidrat. Kalsium silikat hidrat dan kalsium aluminat hidrat merupakan pemegang peranan utama pada pengerasan dan ketahanan semen. Pada penelitian ini, tanah yang terdapat pada timbunan tailing berjenis clay dimungkinkan memiliki kandungan silika dan aluminat. Menurut Faisal [23], reaksi yang terjadi antara $\mathrm{Ca}(\mathrm{OH})_{2}$ dan $\mathrm{SiO}_{2}$ dapat ditulis sebagai berikut:

$$
\begin{gathered}
\mathrm{Ca}(\mathrm{OH})_{2}+\mathrm{SiO}_{2} \rightarrow \mathrm{xCaO} . \mathrm{ySiO}_{2} . \mathrm{H}_{2} \mathrm{O} \\
\text { dimana: } \mathrm{x}, \mathrm{y}, \text { dan } \mathrm{z}=\text { nilai ekivalensi }
\end{gathered}
$$

\section{Uji TCLP}

Sebelum pengujian TCLP, preparasi sampel perlu dilakukan sesuai US EPA Method 1311. Preparasi TCLP meliputi pengecekan $\mathrm{pH}$ dan penentuan cairan ekstraksi yang digunakan. Terdapat 2 cairan ekstraksi, yaitu cairan ekstraksi 1 dan cairan ekstraksi 2. Cairan ekstraksi 1 digunakan jika $\mathrm{pH}$ sampel $<5$, dan cairan ekstraksi 2 digunakan jika $\mathrm{pH}$ sampel $>5$ setelah penambahan 3,5 $\mathrm{ml} \mathrm{HCl} 1 \mathrm{~N}$. Cairan ekstraksi 1 terdiri dari campuran antara larutan $\mathrm{NaOH} 1 \mathrm{~N}$, asam asetat glasial, dan akuades dengan $\mathrm{pH}$ campuran 4,93 $\pm 0,05$. Cairan ekstraksi 2 terdiri dari campuran antara larutan asam asetat glasial dan akuades dengan $\mathrm{pH}$ campuran $2,88 \pm 0,05$. Sampel yang telah dicampur dengan larutan ekstraksi diagitasi dengan rotary agitator selama $18 \pm 2$ jam dengan kecepatan $30 \pm 2$ rpm. Filter disaring menggunakan kertas saring whatman tipe GF/F $47 \mathrm{~mm}$ dengan ukuran pori $0,7 \mu \mathrm{m}$.

Pengujian TCLP merkuri dilakukan menggunakan Atomic Absorption Spectrophotometers (AAS). Hasil uji TCLP merkuri pada kedua variasi sampel dapat dilihat pada Gambar 4.

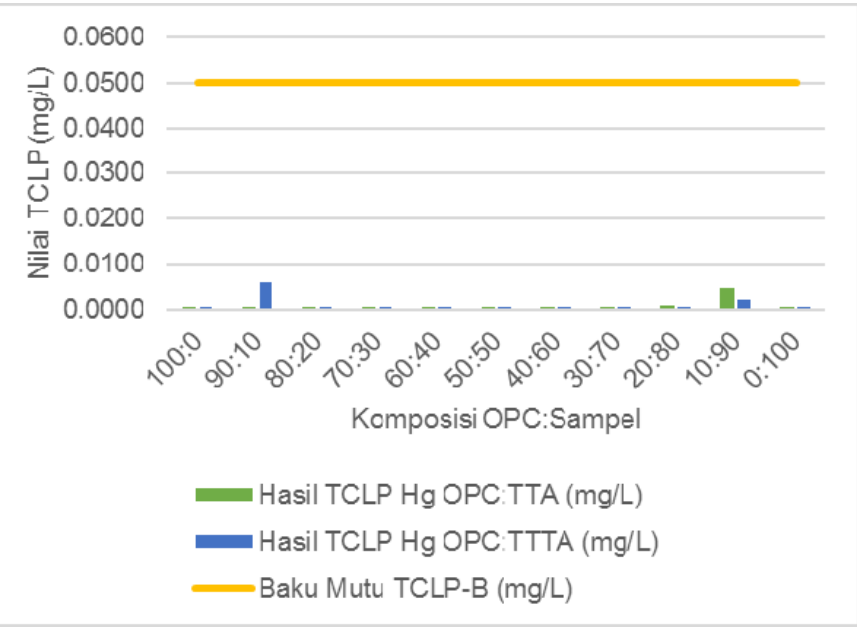

Gambar 4. Hasil Pengujian TCLP Hg Pada Kedua Variasi Timbunan Tailing aktif dan tidak aktif dengan semen Portland

Hasil uji TCLP merkuri pada seluruh sampel memenuhi baku mutu TCLP-B pada PP No. 101 Tahun 2014 yaitu sebesar $0,05 \mathrm{mg} / \mathrm{L}$. Nilai TCLP tersebut memenuhi baku mutu dengan nilai yang jauh lebih rendah. Hasil yang diperoleh pada tiap sampel fluktuatif pada beberapa komposisi. Namun, hampir seluruh sampel memiliki nilai $<0,0005 \mathrm{mg} / \mathrm{L}$. Fluktuasi yang terjadi yaitu pada komposisi 90:10 pada timbunan tailing tidak aktif yang memiliki nlai $0,0059 \mathrm{mg} / \mathrm{L}$. Fluktuasi juga terjadi pada komposisi 10:90 pada timbunan tailing aktif dan tidak aktif yang memiliki nilai TCLP masing - masing $0,0046 \mathrm{mg} / \mathrm{L}$ dan $0,0021 \mathrm{mg} / \mathrm{L}$. Fluktuasi yang terjadi pada komposisi - komposisi tersebut tidak signifikan sehingga nilai TCLP tersebut tidak berada pada posisi outlier.

Dari data yang didapat, bisa dikatakan bahwa merkuri mengalami proses pengendapan yang baik sehingga mobilitas merkuri menjadi lebih rendah. Pengendapan merupakan hasil dari reaksi pengikatan antara merkuri dan binder. 
Pengendapan terjadi karena adanya reaksi antara merkuri ionik $\left(\mathrm{Hg}^{++}\right)$dengan senyawa basa dan karbonat yang terdapat pada semen [23]. Reaksi tersebut dapat dituliskan sebagai berikut:

$$
\begin{aligned}
& \mathrm{Hg}^{++}+\mathrm{OH}^{-} \rightarrow \mathrm{Hg}(\mathrm{OH})_{2} \downarrow \\
& \mathrm{Hg}(\mathrm{OH})_{2} \rightarrow \mathrm{HgO} \downarrow+\mathrm{H}_{2} \mathrm{O} \\
& \mathrm{Hg}^{++} \rightarrow \mathrm{HgCO}_{3} \downarrow
\end{aligned}
$$

Struktur kristalin yang terbentuk dari proses hidrasi akan mengikat logam berat pada limbah setelah menjadi presipitat hidroksida dan garam karbonat [24]. Pada penelitian ini, presipitat dan karbonat yang terbentuk ialah merkuri (II) oksida, merkuri (II) hidroksida, dan merkuri (II) karbonat. Terbentuknya presipitat hidroksida dan garam karbonat pada merkuri dibuktikan oleh nilai TCLP yang didapat pada penelitian ini. Nilai TCLP merkuri tersebut memiliki nilai yang jauh lebih rendah dari baku mutu sehingga dapat disimpulkan bahwa merkuri terikat dengan baik dalam bentuk presipitat hidroksida maupun garam karbonat.

Pada komposisi 100\% timbunan tailing aktif dan tidak aktif, nilai TCLP Hg juga memenuhi standar baku mutu meskipun proses stabilisasi dan solidifikasi tanpa bantuan semen. Hal ini bisa dikarenakan oleh kandungan clay yang terdapat pada kedua timbunan. Berdasarkan penelitian Manohar dkk. [25], tanah clay biasa mampu mengadsorpsi $\mathrm{Hg}$ (II) hingga $20 \%$ pada $\mathrm{pH}$ 4-6. Clay umumnya mengandung $\mathrm{SiO}_{2}$ sebesar $47,19 \%$ dan $\mathrm{Al}_{2} \mathrm{O}_{3} \quad 43,33 \%$ yang mampu mengikat $\mathrm{Hg}$ (II) dalam matriks solid. Kandungan silika dan aluminat pada clay memiliki pengaruh yang besar dalam mengikat merkuri dalam matriks solid. Pada penelitian ini, $\mathrm{pH}$ benda uji dengan komposisi timbunan tailing yang dominan memiliki nilai sekitar 4-6. Hasil pengukuran $\mathrm{pH}$ seluruh benda uji dapat dilihat pada Lampiran Tabel L.1 dan Tabel L.2. Berdasarkan hasil yang didapat, komposisi $100 \%$ timbunan tailing aktif dan komposisi $100 \%$ timbunan tailing tidak aktif dapat dikatakan sebagai komposisi optimum pada penelitian ini. Akan tetapi, penambahan semen portland pada variasi komposisi akan menghasilkan nilai kuat tekan dan TCLP yang jauh lebih baik.

\section{KESIMPULAN/RINGKASAN}

Berdasarkan pembahasan di atas, maka dapat diambil kesimpulan sebagai berikut:

1. Karakteristik timbunan tailing aktif dan tidak aktif yaitu berbentuk seperti lumpur berwarna cokelat keabu-abuan. Timbunan taling aktif dan tidak aktif mengandung unsur clay dengan permeabilitas sekitar 7,32 x 10 $0^{-13}$ hingga $1,03 \times$ $10^{-12} \mathrm{~cm} /$ detik. Kadar air timbunan tailing aktif yaitu sebesar $31,77 \%$ dengan $\mathrm{pH}$ 6,58. Sementara kadar air timbunan tailing tidak aktif sebesar $28 \%$ dengan $\mathrm{pH} 7,3$. Konsentrasi merkuri awal pada timbunan tailing aktif dan tidak aktif melebihi baku mutu PP No. 101 Tahun 2014 sebesar $75 \mathrm{mg} / \mathrm{kg}$, dimana timbunan tailing aktif mengandung merkuri dengan total konsentrasi sebesar 160$318 \mathrm{mg} / \mathrm{kg}$. Timbunan tailing tidak aktif mengandung merkuri dengan total konsentrasi sebesar $94-99 \mathrm{mg} / \mathrm{kg}$. Sementara konsentrasi logam berat lain berada dibawah baku mutu yang ditetapkan.
2. Metode S/S menggunakan semen portland pada timbunan tailing terkontaminasi merkuri mampu memenuhi nilai kuat tekan minimum yang diisyaratkan dan memenuhi nilai TCLP yang ditetapkan. Seluruh variasi komposisi timbunan tailing aktif dan tidak aktif memiliki nilai kuat tekan jauh lebih tinggi dari baku mutu dan nilai TCLP yang jauh lebih rendah dari baku mutu. Komposisi 100\% timbunan tailing aktif dan tidak aktif mampu mengikat merkuri dengan nilai kuat tekan masing - masing sebesar 53 ton $/ \mathrm{m}^{2}$ dan 117 ton $/ \mathrm{m}^{2}$ dan nilai TCLP $<0,0005 \mathrm{mg} / \mathrm{L}$. Komposisi tersebut dapat dikatakan sebagai komposisi optimum pada penelitian ini. Meskipun demikian, penambahan semen portland sebagai binder akan menghasilkan nilai kuat tekan dan TCLP yang jauh lebih baik.

\section{SARAN}

Berdasarkan penelitian yang telah dilakukan, terdapat beberapa saran untuk penelitian lanjutan, antara lain:

1. Perlu adanya penelitian lanjutan mengenai proses $\mathrm{S} / \mathrm{S}$ timbunan tailing dalam skala yang lebih besar dan konsentrasi merkuri yang lebih tinggi, guna mengidentifikasi komposisi yang tepat diaplikasikan pada kondisi lapangan.

2. Perlu adanya penelitian lanjutan dalam mengidentifikasi konsentrasi merkuri yang terdapat pada benda uji setelah pembuatan benda uji dan sebelum pengujian kuat tekan untuk mengidentifikasi mobilitas merkuri selama proses $\mathrm{S} / \mathrm{S}$

3. Perlu adanya penelitian lanjutan untuk mengidentifikasi kandungan clay yang terdapat pada timbunan tailing sehingga dapat diketahui secara pasti pengaruhnya terhadap nilai kuat tekan dan TCLP.

\section{LAMPIRAN}

Tabel L.1. Pengukuran pH Pada Variasi Timbunan Tailing Aktif dengan Semen Portland

\begin{tabular}{cccc}
\hline $\begin{array}{c}\text { Variasi Komposisi } \\
\text { OPC:TTA }\end{array}$ & pH Awal & $\begin{array}{c}\text { pH Setelah } \\
\text { Penambahan } \\
\text { HCl }\end{array}$ & pH Akhir \\
\hline $100: 0$ & 11.59 & 11.15 & 11.98 \\
$90: 10$ & 11.84 & 11.52 & 11.34 \\
$80: 20$ & 12.35 & 11.74 & 11.27 \\
$70: 30$ & 11.55 & 11.05 & 11.15 \\
$60: 40$ & 11.58 & 11.00 & 11.00 \\
$50: 50$ & 11.55 & 10.97 & 10.82 \\
$40: 60$ & 11.62 & 11.03 & 10.13 \\
$30: 70$ & 11.56 & 10.64 & 8.51 \\
$20: 80$ & 11.12 & 8.83 & 6.05 \\
$10: 90$ & 10.95 & 8.21 & 4.55 \\
\hline \hline
\end{tabular}




\begin{tabular}{cccc}
\hline \hline $0: 100$ & 7.85 & 1.97 & 5.20 \\
\hline \hline \multicolumn{4}{c}{ Tabel L.2. Pengukuran pH Pada Variasi Timbunan Tailing Tidak Aktif } \\
& dengan Semen Portland \\
\hline \hline $\begin{array}{c}\text { Variasi Komposisi } \\
\text { OPC:TTTA }\end{array}$ & pH Awal & $\begin{array}{c}\text { pH Setelah } \\
\text { Penambahan HCl }\end{array}$ & pH Akhir \\
\hline $100: 0$ & 11.59 & 11.15 & 11.98 \\
$90: 10$ & 12.32 & 12.06 & 11.25 \\
$80: 20$ & 12.43 & 12.03 & 11.30 \\
$70: 30$ & 11.58 & 11.07 & 11.20 \\
$60: 40$ & 11.54 & 9.80 & 10.40 \\
$50: 50$ & 11.51 & 11.11 & 10.46 \\
$40: 60$ & 12.40 & 11.98 & 6.73 \\
$30: 70$ & 12.28 & 12.35 & 6.67 \\
$20: 80$ & 12.10 & 9.29 & 5.74 \\
$10: 90$ & 11.53 & 6.27 & 4.59 \\
$0: 100$ & 9.61 & 2.60 & 4.66 \\
\hline \hline
\end{tabular}

\section{UCAPAN TERIMA KASIH}

Penulis mengucapkan terima kasih kepada bapak Ranno Marlany Rachman, saudari Wahyuni Dwi Susilowati, Elok Dian Karisma, dan Thaniya Triagustine Kalimantoro selaku rekan kerja yang membantu penulis dalam menyempurnakan penelitian ini. Penulis juga mengucapkan terima kasih kepada bapak Hadi Sutrisno selaku laboran Laboratorium Pemulihan Air dan bapak Eddy Praktikto selaku laboran Laboratorium Manajemen Kualitas Lingkungan yang telah membantu penulis selama pelaksanaan penelitian di Jurusan Teknik Lingkungan FTSP ITS, serta kepada bapak Suharjo dan saudara M. Bassar Ismail selaku tenaga ahli Laboratorium Beton dan Bahan Bangunan yang telah membantu penulis selama pelaksanaan penelitian di Jurusan Teknik Sipil FTSP ITS.

\section{DAFTAR PUSTAKA}

[1] Lottermoser, B. G., Mine Wastes "Characterization, Treatment and Environmental Impacts” ( $3^{\text {rd }}$ Edition), London: Springer (2010).

[2] Setiabudi, B. T. "Penyebaran Merkuri Akibat Usaha Pertambangan Emas di Daerah Sangon, Kabupaten Kulon Progo, D. I. Yogyakarta". Kolokium Hasil Lapangan-DIM (2005).

[3] Larasati, R., Setyono, P., dan Sambowo, K. A. "Valuasi Ekonomi Eksternalitas Penggunaan Merkuri Pada Pertambangan Emas Rakyat dan Peran Pemerintah Daerah Mengatasi Pencemaran Merkuri (Studi Kasus Pertambangan Emas Rakyat di Kecamatan Kokap Kulon Progo)". Jurnal EKOSAINS 4 (2012), 1:48-63.

[4] Ogola, J. S., Mitullah, W. V., dan Omulo, M. A. "Impact of Gold Mining on The Environment and Human Health: a Case Study in The Migori Gold Belt, Kenya”. Environmental Research (2002), 107:89-97.

[5] Peraturan Pemerintah No. 101 Tahun 2014 tentang Pengelolaan Limbah Bahan Berbahaya dan Beracun. Jakarta: Sekretaris Negara Republik Indonesia.

[6] Kalimantoro, T. T. "Stabilisasi/Solidifikasi Tailing Tambang Emas Rakyat Kulon Progo Menggunakan Semen Portland dan Tanah Tras". belum dipublikasikan.

[7] Andrés, A., Ibáňez, R., Ortiz, I., dan Irabien, J. A. "Experimental Study of The Waste Binder Anhydrite in The Solidification/Stabilization
Process of Heavy Metal Sludges". Journal of Hazardous Materials (1998), 57:155-168.

[8] Chang, J. E., Lin, T. T., Ko, M. S., dan Liaw, D. S. "Stabilization/Solidification of Sludges Containing Heavy Metals by Using Cement and Waste Pozzolans". Journal of Environmental Science and Health A34 (2008), 5:1143-1160.

[9] Ganjidoust, H., Hassani, A., dan Ashkiki, A. B. "Cement-Based Solidification/Stabilization of Heavy Metal Contaminated Soils with The Objective of Achieving High Compressive Strength for The Final Matrix”. Scientia Iranica 16 (2009), 2:107-115.

[10] Karamalidis, A. K. dan Voudrias, E. A. "Cement-Based Stabilization/Solidification of Oil Refinery Sludge: Leaching Behavior of Alkanes and PAHs". Journal of Hazardous Materials 148 (2007), 122-135.

[11] U.S. EPA, Methods for Collection, Storage and Manipulation of Sediments for Chemical and Toxicological Analyses: Technical Manual, Washington: U.S. Environmental Protection Agency (2001).

[12] U.S. EPA, Treatment Technologies for Mercury in Soil, Waste, and Water, Washington: U.S. Environmental Protection Agency (2007).

[13] Faimun, Buku Petunjuk Praktikum Teknologi Beton dan Bahan, Surabaya: Jurusan Teknik Sipil ITS.

[14] Indrayurmansyah. "Pentingnya Perawatan Beton untuk Mencapai Nilai Kekuatan". Jurnal $R$ \& B 1 (2001), 2:1-7.

[15] Raheem, A. A., Soyingbe, A. A., dan Emenike, A. J. "Effect of Curing Methids on Density and Compressive Strength of Concrete". Internasional Journal of Applied Science and Technology 4 (2013), 3:55-64.

[16] Badan Standarisasi Nasional. "Metode Pengujian Kuat Tekan Beton". SNI 03-1974-1990 (1990).

[17] Keputusan Kepala Badan Pengendalian Dampak Lingkungan No. 03 Tahun 1995 tentang Persyaratan Teknis Pengolahan Limbah Bahan Berbahaya Beracun. Badan Pengendalian Dampak Lingkungan.

[18] U.S. EPA, Toxicity Characteristic Leaching Procedure, WashingtonL U.S. Environmental Protection Agency (1992).

[19] Banunaek, Z. A. "Pencemaran Merkuri di Lahan Pertambangan Emas Rakyat dan Upaya Pengendaliannya". belum dipublikasikan.

[20] Pollard, S. J. T., Montgomery, D. M., Sollars, C. J., dan Perry, R. "Organic Compounds in The Cement-Based Stabilisation/Solidification of Hazardous Mixed Wastes-Mechanistic and Process Considerations". Journal of Hazardous Materials (1991), 28: 313-327.

[21] He, C., Osbæk, B., dan Makovicky, E. "Pozzolanic Reactions of Six Principal Clay Minerals: Activation, Reactivity Assessments, And Technological Effects". Cement and Concrete Research 8 (1995), 25: 1691-1702.

[22] Sari, E. "Studi Pemanfaatan Abu Incinerator TPA Keputih Sebagai Bahan Campuran Semen untuk Mengikat Logam Berat $\mathrm{Cu}$ dengan Proses Solidifikasi-Stabilisasi". Surabaya: Jurusan Teknik Lingkungan FTSP ITS (2000).

[23] Faisal, S. "Stabilisasi/Solidifikasi Tanah Tercemar Merkuri Simulasi Menggunakan Semen Portland dan Fly Ash". Surabaya: Jurusan Teknik Lingkungan FTSP ITS (2015).

[24] Trihadiningrum, Y, Pengelolaan Limbah Bahan Berbahaya dan Beracun (B3), Surabaya: ITS Press (2000).

[25] Manohar, D. M., Krishnan, K. A., dan Anirudhan, T. S. "Removal of Mercury(II) from Aqueous Solutions and Chlor-Alkali Industry Wastewater Using 2-Mercaptobenzimidazole-Clay". Waste Research (2002), $36: 1609-1619$. 